Progressive Physics Journal
Volume 2, Nomor 1, Juni 2021
ISSN 2722-7707 (online)
http://jurnal.fmipa.unmul.ac.id/index.php/ppj/index

\title{
MENENTUKAN TINGKAT INTENSITAS RADIASI UV YANG DITERIMA PEKERJA PENGELASAN DENGAN TITIK AREA MATA, SIKU, DAN BETIS
}

\author{
${ }^{1}$ Muliana ${ }^{1,2}$ Kadek Subagiada ${ }^{1,2}$ Adrianus Inu Natalisanto \\ ${ }^{1}$ Program Studi Fisika, Fakultas MIPA, Universitas Mulawarman \\ ${ }^{2}$ Laboraturium Fisika Dasar UNMUL, Fakultas MIPA, Universitas Mulawarman \\ *Email : mulianaaa313@gmail.com
}

\begin{abstract}
The aim of this study is to measure the UV intensity received by the welders during working time and compare the results of measured radiation intensity which is obtained with the NAB in Regulation of the Minister of Manpower No. 05 of 2018 that is $0,0008 \mathrm{~mW} / \mathrm{cm}^{2}$. The reason for using this NAB is for compare value while welding process with the value were allowed from Regulation of the Minister of Manpower. This study has been done in some workshops using the UV Meter and focused on the welders' eye, elbow and calf area with 10 repetitions in each area. The results for eye area were $0.0749 \mathrm{~mW} / \mathrm{cm}^{2}$, for elbow area were $0.0843 \mathrm{~mW} / \mathrm{cm}^{2}$ and for calf area were $0.0934 \mathrm{~mW} / \mathrm{cm}^{2}$ and all the results obtained exceed the NAB. The high value is caused by the environmental conditions is open and also affected by indeterminate sunlight, the risks received the welders in watery eye and headache because of the welder are disobey in using PPE while welding process.
\end{abstract}

Keywords : Intensity, NAB, UV Radiation, UV Meter, Welding

\section{PENDAHULUAN}

\section{A. Latar Belakang}

Radiasi UV (Ultraviolet) pada pengelasan termasuk dalam radiasi UVC dengan panjang gelombang pendek. Radiasi UVC merupakan jenis radiasi UV yang paling merusak, meskipun tidak dianggap sebagai resiko kanker kulit, namun sinar UVC dapat menyebabkan kerusakan parah pada mata dan kulit manusia. Pada proses pengelasan salah satu bagian tubuh yang terpapar adalah mata, mata merupakan bagian tubuh yang sangat penting. Jika mata terpapar langsung oleh sinar UV, maka hal ini dapat menyebabkan gangguan pada mata. Oleh karena itu, diperlukan menggunakan kacamata pelindung atau biasa disebut goggles beserta dengan helm las [2].

Kulit yang terkena paparan radiasi sinar UV secaea terus-menerus akan mengalami perubahan struktur dan komposisi serta akan timbulnya oksidatif pada kulit. Sinar UV seringkali disebut sunburn spectrum yang mampu merusak membran sel. Hal ini mengakibatkan kulit terbakar dan menjadi kemerahan, merusak sel-sel kulit selanjutnya mengakibatkan kerusakan mekanisme regenerasi dari sel-sel kulit. Sinar UVA juga bisa menimbulkan efek terbakar pada kulit namun lebih lemah jika dibandingkan dengan efek paparan sinar UVB [3].

Berikut ini adalah manfaat dan tujuan penelitian yaitu: Mengukur intensitas UV yang diterima pekerja las dengan menggunakan 1 jam waktu kerja. Membandingkan hasil pengukuran intensitas radiasi yang didapatkan dengan NAB yang ditetapkan oleh Peraturan Menteri Ketenagakerjaan No.05 Tahun 2018. Dijadikan sebagai acuan untuk melindungi pekerja berdasarkan Permenaker No.5 Tahun 2018. Meninjau hasil pengukuran sinar radiasi UV dan 
membandingkan dengan NAB yang ditetapkan oleh Peraturan Menteri Ketenagakerjaan dan No.05 Tahun 2018.

\section{TINJAUAN PUSTAKA}

\section{A. Radiasi ultraviolet}

Radiasi ultraviolet atau radiasi ultraungu (sering disingkat UV, dari Bahasa Inggris Ultraviolet) adalah radiasi elektromagnetis terhadap panjang gelombang yang lebih pendek dari daerah dengan sinar tampak, tetapi lebih panjang dari sinar- $X$ yang kecil. Jenis radiasi UV dibagi menjadi tiga bagian, di antaranya adalah UVA $(380-315 \mathrm{~nm})$, yang juga disebut "Gelombang Panjang" UVB (315-280 nm), yang juga disebut "Gelombang Medium" dan UVC (280-10 nm), juga disebut "Gelombang Pendek" (Short Wave) [8].

Berikut ini beberapa dampak yang diterima saat terpapar UV secara langsung:

a. Kulit terasa seperti terbakar

Sinar ultraviolet juga dapat membuat kulit memilikii gejala seperti terbakar. Hal ini biasanya disebabkan oleh paparan sinar UVB.

b. Dapat menimbulkan eritema,

Eritema merupakan kondisi dimana kulit kaki mengalami kemerahan dan bengkak. Hal ini disebabkan oleh paparan sinar UVB.

c. Menimbulkan penyakit katarak,

Katarak merupakan kondisi mata yang tertutupi atau terhalang selaput-selaput tertentu sehingga membuat penglihatan menjadi berkabut dan cukup jelas. Selain faktor usia, paparan sinar UV juga menjadi salah satu pemicu timbulnya katarak.

d. Dapat memicu pertumbuhan sel kanker

Paparan sinar UV dapat menimbulkan terjadinya kerusakan fotokimia pada DNA dari sel-sel yang berada di dalam tubuh. Hal ini akan memicu terbentuknya kanker, terutama kanker kulit pada manusia.

e. Radiasi sinar UVA yang menembus dermis dapat merusak sel kulit,

f. Kulit dapat kehilangan elastisitas Paparan sinar UVA yang dapat menembus bagian demis kulit dapat merusak sel-sel yang berada pada dermis. Hal ini membuat elastisitas kulit menjadi berkurang.

g. Kerut pada bagian kulit

Kerutan pada kulit merupakan salah satu efek samping dari hilangnya dan berkurangnya elastisitas kulit.

h. Kanker kulit

Beberapa jenis kanker kulit disebabkan oleh sinar UV. Sinar matahari di siang dan sore hari sangat riskan untuk merusak kulit

[1].

\section{B. Pengelasan}

Pengelasan merupakan proses dimana sumber energi panas yang dihasilkan dari energi listrik dirubah menjadi energi panas yang digunakan untuk melelehkan elektroda/kawat las dan logam yang ingin disambung sehingga menghasilkan percikan api dari elektroda yang terbakar. Pengelasan (welding) diartikan sebagai salah satu teknik penyambungan logam dengan cara mencairkan sebagian logam tambahan dan menghasilkan sambungan yang berkelanjutan. Risiko bahaya yang paling banyak mempengaruhi tenaga kerja pada saat mengelas adalah bahaya radiasi (welding radiation) [9]. 


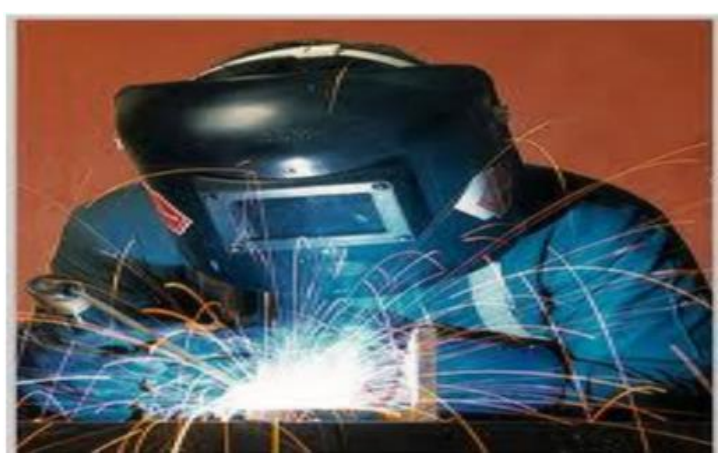

Gambar 1. Proses Pengelasan [4]

\section{Nilai Ambang Batas (NAB)}

NAB merupakan singkatan dari nilai ambang batas yang digunakan sebagai (pedoman) rekomendasi pada praktek higiene perusahaan dalam melakukan pelaksanaan lingkungan kerja sebagai upaya untuk mencegah dampak negatif terhadap kesehatan. Dengan demikian NAB antara lain dapat pula digunakan:

a. Sebagai kadar standar untuk perbandingan.

b. Sebagai pedoman untuk perencanaan proses produksi dan perencanaan teknologi pengendalian bahaya-bahaya dilingkungan kerja.

c. Menentukan pengendalian bahan proses produksi terhadap bahan yang lebih beracun dengan bahan ang sangat beracun.

d. Membantu menentukan diagnosis gangguan kesehatan, timbulnya penyakit-penyakit dan hambatan-hambatan efesiensi kerjaakibat faktor kimiawi dengan bantuan pemeriksaan biologik

[7].

Tabel 1. Waktu Pemaparan Radiasi Sinar UV yang ditetapkan oleh Permenaker No.5 Tahun 2018 [7]

\begin{tabular}{|c|c|}
\hline Masa Pemaparan & Radiasi Efektif $\mathrm{mW} / \mathrm{cm}^{2}$ \\
\hline 8 jam & 0,0001 \\
\hline 4 jam & 0,0002 \\
\hline 2 jam & 0,0004 \\
\hline 1 jam & 0,0008 \\
\hline 30 menit & 0,0017 \\
\hline 15 menit & 0,0033 \\
\hline 10 menit & 0,005 \\
\hline 5 menit & 0,01 \\
\hline 1 menit & 0,05 \\
\hline 30 detik & 0,1 \\
\hline 10 detik & 0,3 \\
\hline 1 detik & 3 \\
\hline 0,5 detik & 6 \\
\hline 0,1 detik & 30 \\
\hline
\end{tabular}

[7]. 
Dari Tabel 1. dapat dilihat waktu masa pemaparan yang diperkenan oleh Peraturan Mentri Ketenagakerjaan dari tingkat radiasi terkecil hingga terbesar. Jika masa pemaparan lebih lama maka radiasi yang diterima pekerja lebih kecil dan sebaliknya [7].

Pada pengolahan data terkait dengan nilai ambang batas, dapat diketahui besar kecilnya intensitas yang diterima pekerja. Intensitas adalah energi gelombang elektromagnetik tiap saat yang mengenai suatu permukaan atau dirumuskan sebagai berikut :

$$
\mathrm{I}=\frac{P}{\mathrm{~A}}
$$

dengan I merupakan Intensitas, P merupakan daya (bersatuan watt) dan A merupakan luas permukaan yang menyerap energi (bersatuan $\mathrm{cm}^{2}$ ) [7].

Berdasarkan data yang diperoleh dari proses pengelasan yang dilakukan dapat dilakukan perhitungan sebagai berikut:

a. Menghitung intensitas rata-rata sinar Uv pengelasan menggunakan rumus:

$$
\mathrm{I}=\frac{1}{10} \sum_{i=0}^{10} \mathrm{I}_{\mathrm{i}}
$$

b. Menghitung ketidakpastian dan ketidakpastian relatif dengan rumus:

$$
\begin{aligned}
\Delta \mathrm{I}_{\mathrm{M}} & =\sqrt{\frac{\sum_{\mathrm{i}=1}^{10}\left(\mathrm{I}_{\mathrm{i}-\mathrm{I}}\right)^{2}}{10(10-1)}} \\
\Delta \mathrm{I}_{\mathrm{Mr}} & =\frac{\Delta \mathrm{I}_{\mathrm{PM}}}{\overline{\mathrm{I}}_{\mathrm{PM}}} \times 100 \%
\end{aligned}
$$

c. Mengkonversi (mengubah) data $\mu \mathrm{W} / \mathrm{m}^{2}$ menjadi $\mathrm{mW} / \mathrm{cm}^{2}$ dengan rumus:

$1 \mu$ (microwatt) $=0,001$ miliwatt

$$
\bar{I}_{\text {PM }} \times 0,001 \text { miliwatt }
$$

5. Membuat diagram batang intensitas sinar radiasi UV

6. Membandingkan hasil pengukuran pada diagram batang

7. Hasil Analisis

\section{METODE PENELITIAN}

Waktu Dan Tempat Penelitian ini dilaksanakan pada bulan Maret 2020 sampai dengan Desember 2020 dibeberapa Bengkel Las jl.Gn.Lingai di Samarinda. Kalimantan Timur.

Alat dan Bahan UV Meter, Stopwatch, Peralatan Las, Meteran atau penggaris panjang, 2 Obyek (Pengelas). Prosedur Penelitian ini dilakukan dengan tahapan sebagai berikut: Tahap Studi Literatur yaitu tahap yang berguna untuk mengumpulkan informasi mengenai penelitian yang akan dilakukan dari berbagai sumber literatur seperti buku maupun dari penelitian sebelumnya. Observasi Lapangan yaitu berguna untuk mengetahui lokasi terlebih dahulu sebelum melakukan penelitian agar dapat menentukan tempat penelitian yang tepat. Tahap Eksperimen yaitu melakukan pengujian terhadap objek pengelasan antara pengelas dan alat las berdasarkan jarak dan waktu yang telah di tentukan. Analisis data berdasarkan data pengelasan yang dilakukan dapat dilakukan perhitungan sebagai berikut:

a. Menghitung intensitas rata-rata sinar Uv pengelasan menggunakan rumus:

$$
\mathrm{I}=\frac{1}{10} \sum_{i=0}^{10} \mathrm{I}_{\mathrm{i}}
$$

b. Menghitung ketidakpastian dan ketidakpastian relatif dengan rumus: 


$$
\begin{aligned}
\Delta \mathrm{I}_{\mathrm{M}} & =\sqrt{\frac{\sum_{\mathrm{i=1}}^{10}\left(\mathrm{I}_{\mathrm{i}-\mathrm{I}}\right)^{2}}{10(10-1)}} \\
\Delta \mathrm{I}_{\mathrm{Mr}} & =\frac{\Delta \mathrm{I}_{\mathrm{PM}}}{\overline{\mathrm{I}}_{\mathrm{PM}}} \times 100 \%
\end{aligned}
$$

c. Mengkonversi (mengubah) data $\mu \mathrm{W} / \mathrm{m}^{2}$ menjadi $\mathrm{mW} / \mathrm{cm}^{2}$ dengan rumus:

$1 \mu$ (microwatt) $=0,001$ miliwatt

$$
\bar{T}_{\text {PM }} \times 0,001 \text { miliwatt }
$$

5. Membuat diagram batang intensitas sinar radiasi UV

6. Membandingkan hasil pengukuran pada diagram batang

7. Hasil Analisis

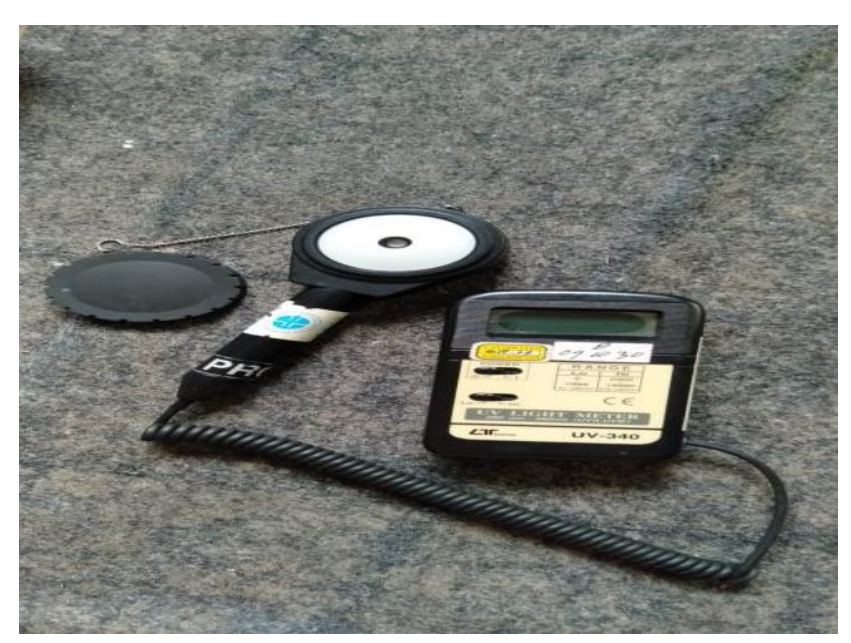

Gambar 2. UV Meter

\section{HASIL DAN PEMBAHASAN}

\section{A. HASIL}

Tabel 2. Nilai Intensitas Radiasi UV Yang Diterima Pekerja Pengelas 1

\begin{tabular}{|c|c|c|c|c|c|c|c|}
\hline No & $\begin{array}{c}\text { Jarak } \\
\text { Pengukuran }\end{array}$ & $\begin{array}{c}\text { Tititk yang } \\
\text { diukur }\end{array}$ & Satuan & $\begin{array}{c}\text { Terukur } \\
\mathbf{m W} / \mathbf{c m} 2\end{array}$ & $\begin{array}{c}\text { Lama } \\
\text { Pajanan }\end{array}$ & NAB & Penilaian \\
\hline \multirow{2}{*}{1} & \multirow{3}{*}{$30 \mathrm{~cm}$} & Area Mata & $\mathrm{mW} / \mathrm{cm}^{2}$ & 0,0749 & 60 menit & 0,0008 & $>\mathrm{NAB}$ \\
\cline { 3 - 8 } & & Area Siku & $\mathrm{mW} / \mathrm{cm}^{2}$ & 0,0843 & 60 menit & 0,0008 & $>\mathrm{NAB}$ \\
\cline { 3 - 8 } & & Area Betis & $\mathrm{mW} / \mathrm{cm}^{2}$ & 0,0934 & 60 menit & 0,0008 & $>\mathrm{NAB}$ \\
\hline \multirow{2}{*}{2} & \multirow{3}{*}{$100 \mathrm{~cm}$} & Area Mata & $\mathrm{mW} / \mathrm{cm}^{2}$ & 0,0516 & 60 menit & 0,0008 & $>\mathrm{NAB}$ \\
\cline { 3 - 8 } & & Area Siku & $\mathrm{mW} / \mathrm{cm}^{2}$ & 0,0572 & 60 menit & 0,0008 & $>\mathrm{NAB}$ \\
\cline { 3 - 8 } & & Area Betis & $\mathrm{mW} / \mathrm{cm}^{2}$ & 0,054 & 60 menit & 0,0008 & $>\mathrm{NAB}$ \\
\hline
\end{tabular}


Tabel 3. Nilai Intensitas Radiasi UV Yang Diterima Pekerja Pengelas 2

\begin{tabular}{|c|c|c|c|c|c|c|c|}
\hline No & $\begin{array}{c}\text { Jarak } \\
\text { Pengukuran }\end{array}$ & $\begin{array}{c}\text { Tititk yang } \\
\text { diukur }\end{array}$ & Satuan & $\begin{array}{c}\text { Terukur } \\
\mathbf{m W} / \mathbf{c m} 2\end{array}$ & $\begin{array}{c}\text { Lama } \\
\text { Pajanan }\end{array}$ & NAB & Penilaian \\
\hline \multirow{2}{*}{1} & \multirow{3}{*}{$30 \mathrm{~cm}$} & Area Mata & $\mathrm{mW} / \mathrm{cm}^{2}$ & 0,1227 & 60 menit & 0,0008 & $>$ NAB \\
\cline { 3 - 8 } & & Area Siku & $\mathrm{mW} / \mathrm{cm}^{2}$ & 0,1816 & 60 menit & 0,0008 & $>$ NAB \\
\cline { 3 - 8 } & & Area Betis & $\mathrm{mW} / \mathrm{cm}^{2}$ & 0,1875 & 60 menit & 0,0008 & $>$ NAB \\
\hline \multirow{2}{*}{2} & \multirow{3}{*}{$100 \mathrm{~cm}$} & Area Mata & $\mathrm{mW} / \mathrm{cm}^{2}$ & 0,1041 & 60 menit & 0,0008 & $>$ NAB \\
\cline { 3 - 8 } & & Area Siku & $\mathrm{mW} / \mathrm{cm}^{2}$ & 0,1317 & 60 menit & 0,0008 & $>$ NAB \\
\cline { 3 - 8 } & & Area Betis & $\mathrm{mW} / \mathrm{cm}^{2}$ & 0,1379 & 60 menit & 0,0008 & $>\mathrm{NAB}$ \\
\hline
\end{tabular}

\section{B. Diagram Batang}

Pada hasil nilai konversi yang disajikan pada Tabel $\mathbf{2}$ dan 3, diperoleh diagram batang intensitas radiasi sinar UV yang dapat dilihat pada Gambar $\mathbf{3}$ dan Gambar $\mathbf{4}$ sebagai berikut:

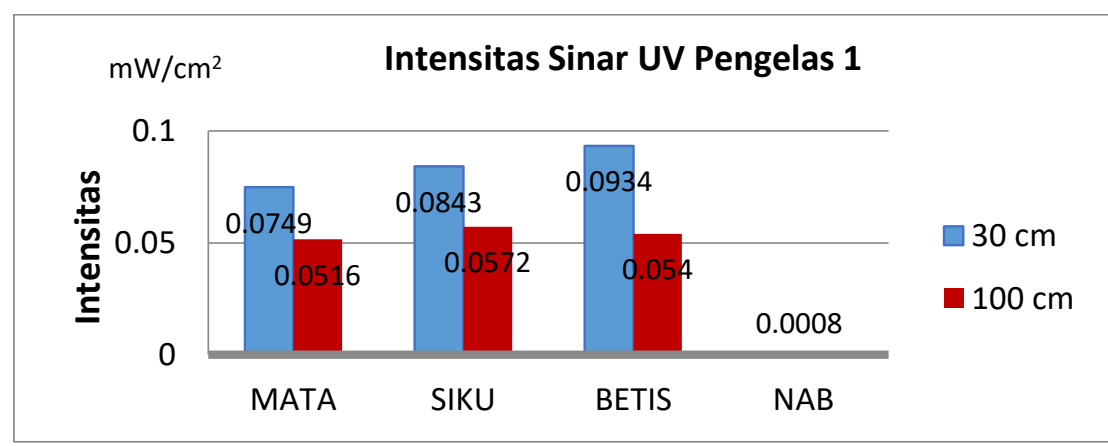

Gambar 3. Diagram Batang Intensitas Radiasi UV dari Pengelas 1

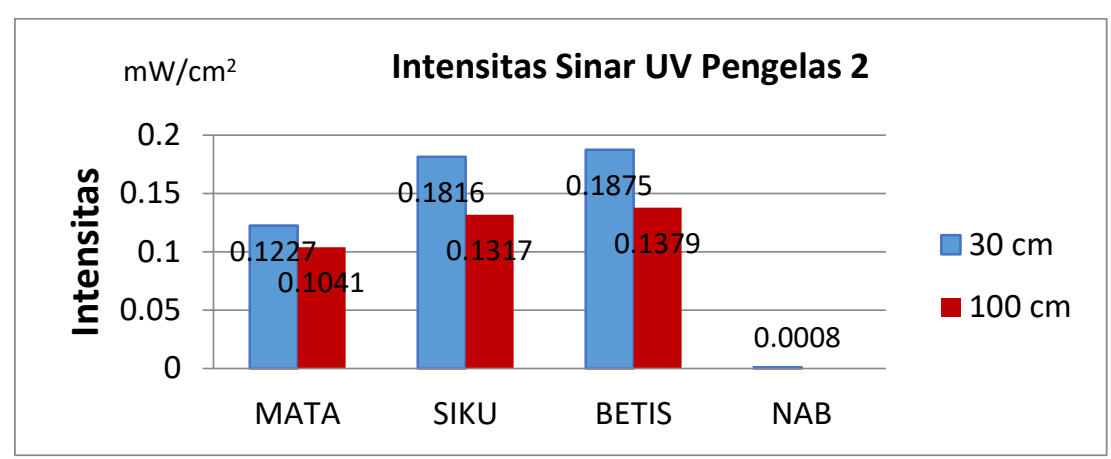

Gambar 4. Diagram Batang Intensitas Radiasi UV dari Pengelas 2

Pada penelitian radiasi UV pengelasan dilakukan pengukuran dengan 2 obyek orang pekerja las dengan lokasi lingkungan yang terbuka dan menggunakan 2 jarak pengukuran, yaitu $30 \mathrm{~cm}$ dan $100 \mathrm{~cm}$. Pengukuran dilakukan hanya pada 3 titik area yang diukur yaitu sejajar area mata, siku dan betis karena area tersebut rentan terkena UV? jika tidak menggunakan alat pelindung diri khusus, pengambilan data sebanyak 10 data pada masing-masing titik area dengan posisi pekerja pengelasan jongkok. Hasil nilai yang diperoleh setelah mengonversikan $\mu \mathrm{W} / \mathrm{cm}^{2}$ menjadi $\mathrm{mW} / \mathrm{cm}^{2}$ dengan jarak pengukuran $30 \mathrm{~cm}$, maka diperoleh hasil rata-rata obyek pertama pengelas $10,0842 \mathrm{~mW} / \mathrm{cm}^{2}$, jarak $100 \mathrm{~cm}$ yaitu 0,0542 dan obyek kedua (pengelas 2) diperoleh hasil rata-rata dengan jarak $30 \mathrm{~cm}$ yaitu $0,1639 \mathrm{~mW} / \mathrm{cm}^{2}$, jarak $100 \mathrm{~cm}$ yaitu $0,1245 \mathrm{~mW} / \mathrm{cm}^{2}$. Pada diagram batang diatas dapat dilihat nilai pada jarak $30 \mathrm{~cm}$ lebih 
besar dari nilai jarak $100 \mathrm{~cm}$ dan dapat disimpulkan bahwa jarak adalah faktor utama besar kecilnya nilai yang diterima pekerja, sementara pada nilai yang diterima obyek 2 lebih besar dari nilai obyek 1 karena pengambilan data obyek 2 kondisi cuaca cenderung panas dari obyek 1 dengan cuaca mendung yang merupakan faktor kedua besar kecilnya intensitas yang diterima. Adapun dampak atau resiko terbesar dari terpapar UV pengelasan sebagaimana yang telah disampaikan dan dirasakan langsung oleh pekerja las pada penelitian ini adalah mata berair dan sakit kepala karena ketidakdisiplinan menggunakan APD (alat pelindung diri) lengkap sesuai peraturan yang ditetapkan saat melakukan pengelasan. Untuk selanjutnya, dalam melakukan pengukuran sinar radiasi UV ini dapat dilakukan ditempat-tempat lainnya seperti di rumah sakit dan sekolah-sekolah. Agar setiap aktivitas yang dilakukan aman dari bahaya UV yang yang ada disekitar kita menggunakan alat UV Meter.

\section{KESIMPULAN}

Intensitas UV yang diterima pekerja las dalam waktu 1 jam waktu kerja diperoleh hasil dengan rata-rata obyek 1 sebesar $0,0842 \mathrm{~mW} / \mathrm{cm}^{2}$ dan obyek 2 sebesar 0,1639 $\mathrm{mW} / \mathrm{cm}^{2}$. Berdasarkan hasil pengukuran intensitas radiasi sinar UV selama penelitian ini didapatkan bahwa pengukuran di lokasi pengelasan melebihi NAB (nilai ambang batas) yang ditetapkan oleh ketentuan peraturan PERMENAKER No.5 Tahun 2018.

\section{UCAPAN TERIMA KASIH}

Bapak Dr. Eng. Idris Mandang, M.Si. selaku Dekan Fakultas Matematika dan IImu Pengetahuan Alam, Universitas Mulawarman. Bapak Dr. Djayus, MT selaku Ketua Jurusan Fisika. Bapak Kadek Subagiada, S.Si, M.Si, selaku dosen pembimbing I dan Bapak Dr. Adrianus Inu natalisanto, M.Si, selaku dosen pembimbing II yang banyak memberi masukan dan pertimbangan dalam penyusunan kripsi. Ibu Dr. Pratiwi Sri Wardani, M.Kes selaku dosen penguji I dan Ibu Devina Rayzy P. S.P.,M.Sc selaku dosen penguji II yang telah memberi masukan. Ibu Ferawati,, S.si, selaku pembimbing lapangan yang telah meluangkan waktunya untuk membimbing penulis selama kegiatan penelitian.

\section{DAFTAR PUSTAKA}

[1] Ana. 2014. Sinar Ultra Violet. Jakarta. Badan Penelitian dan Pengembangan Kesehatan

[2] Anizar. 2009. Sinar Radiasi Ultraviolet yang diterima tubuh manusia. Yogyakarta: Graha IImu

[3] Alatas. 2004. Efek Radiasi Pengion dan Non Pengion pada Manusia. Buletin Alara. Web: http://jurnal.unpad.ac.id/farmaka (diaksses pada 26 Agustus 2020 pukul 08.48 WITA)

[4] Darmini. 2007. Analisis Faktor yang berhubungan terhadap Ketajaman Penglihatan pada Pekerja Bengkel Bagian Pengelasan Karbit, Semarang: Skripsi IKM UNNES

[5] Dewi. 2018. Fisika Radiasi dan Aplikasi Dalam Kehidupan. Jakarta. Universitas Muhammadiyah Mataram

[6] Fandy. 2003. Gejala Fotokeratitis akut Akibat Radiasi Sinar Ultraviolet Pada Pekerja Las. Jember. Kampus Tegal Boto Web: http://lib.ui.ac.id/file (diaksses pada 10 Agustus 2020 pukul 12.19 WITA)

[7] Permenaker. 2018. Keselamatan dan Kesehatan Kerja Lingkungan Kerja No.5 Tahun 2018. Jakarta. Menteri Ketenagakerjaan Republik Indonesia.

Web: https://www.basishukum.com/permenaker/5/2018

[8] Putra. 2012. Radiasi Elektromagnetis. Jakarta: Dapartemen Kesehatan RI

[9] Siswanto. 2002. Penggunaan Alat Pelindung Wajah pada Pekerja Las Listrik. Malang: Jurusan Teknik Mesin 